\title{
Hemoglobin concentrations and associated factors in adolescents from Recife, Brazil ${ }^{1}$
}

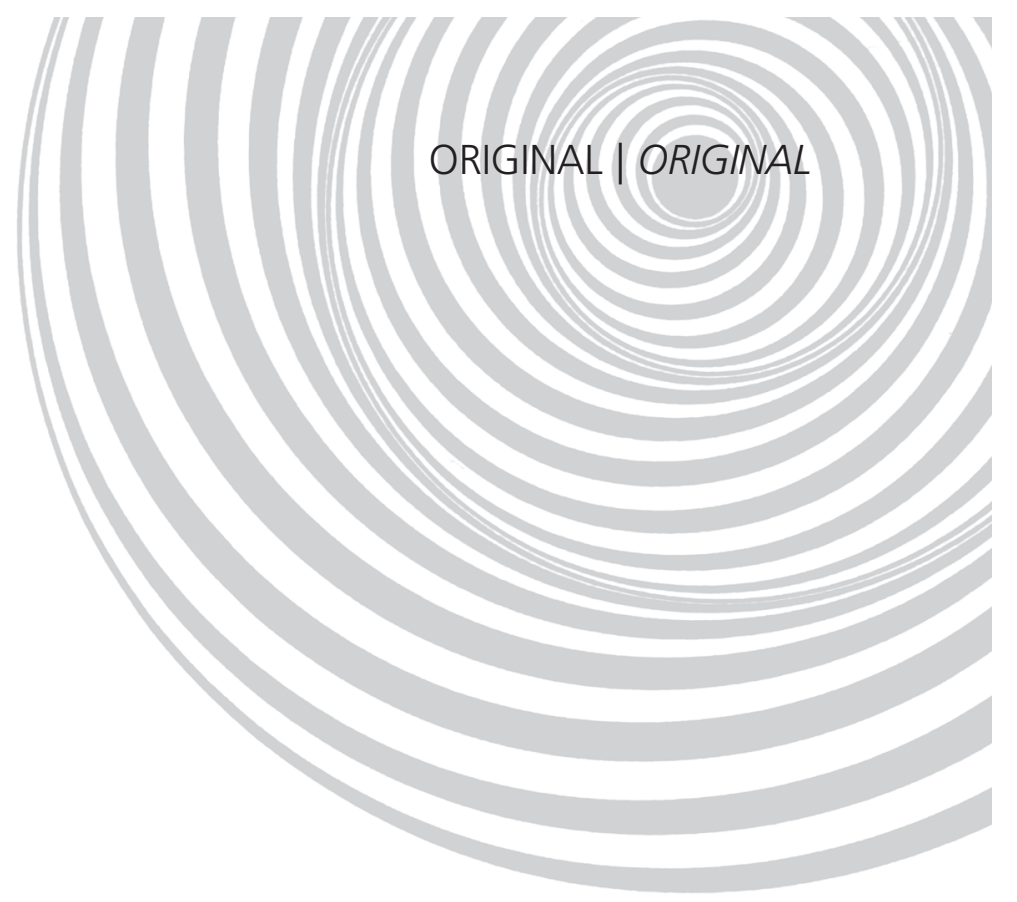

\section{Concentrações de hemoglobina \\ e fatores associados em \\ adolescentes de Recife}

Elisângela Barros Soares MENDONÇA²

Lilian Ferreira MUNIZ ${ }^{3}$

IIma Kruze Grande de ARRUDA 4

Alcides da Silva DINIZ4

A B S T R A C T

\section{Objective}

To estimate the prevalence of anemia and associated factors in adolescents from the city of Recife in Pernambuco state.

\section{Methods}

This is a cross-sectional study, involving a random sample of 256 adolescents of both genders, aged 13 to 18 , whose hemoglobin concentrations were evaluated, along with their nutritional status and socioeconomic and demographic characteristics.

\section{Results}

The prevalence of inadequate hemoglobin concentrations was 10.2\% [C195\%=6.7-14.5], reaching levels considered as mild anemia ( $9 \mathrm{~g} / \mathrm{dL}<$ hemoglobin $<12 \mathrm{~g} / \mathrm{dL}$ ). Female students had lower mean hemoglobin concentrations in all age groups $(p<0.001)$. No association was observed between hemoglobin concentrations and nutritional status $(p>0.05)$, nor with socioeconomic or demographic characteristics $(p>0.05)$.

1 Article based on the doctoral dissertation of EBS MENDONÇA, intitled "Concentrações de hemoglobina em adolescentes e sua associação com as habilidades de ordenação temporal e atenção auditiva". Universidade Federal de Pernambuco; 2013.

2 Fonoaudióloga. Gerência Regional de Educação da Mata Norte do Estado de Pernambuco, Núcleo de Atenção do Servidor. R. Coelho Neto, s/n., Juá, 55800-000, Nazaré da Mata, PE, Brasil. Correspondência para/Correspondence to: EBS MENDONÇA. E-mail: <ellissoares@outlook.com>.

${ }^{3}$ Universidade Federal de Pernambuco, Centro de Ciências da Saúde, Departamento de Fonoaudiologia. Recife, PE, Brasil.

${ }^{4}$ Universidade Federal de Pernambuco, Centro de Ciências da Saúde, Departamento de Nutrição. Recife, PE, Brasil.

Support: Conselho Nacional de Desenvolvimento Científico e Tecnológico (Process nº 474146/2006-5). 


\section{Conclusion}

Although the prevalence of anemia was low and classified as a mild health problem, preventive nutrition education involving the dissemination of healthy eating habits in schools and encouraging the consumption of iron-rich foods are strongly recommended.

Indexing terms: Anemia. Adolescent. Nutritional status. Epidemiology. Socioeconomic factors.

\section{RE S U M O}

\section{Objetivo}

Estimar a prevalência de anemia e fatores associados em adolescentes do Recife, Pernambuco.

\section{Métodos}

Estudo de corte transversal, envolvendo uma amostra aleatória de 256 adolescentes, de 13 a 18 anos, de ambos os sexos. Foram avaliadas as concentrações de hemoglobina, o estado nutricional e as características socioeconômicas e demográficas.

\section{Resultados}

A prevalência de concentrações inadequadas de hemoglobina foi de 10,2\% [IC95\%=6,7-14,5], situando-se em patamares que configuram a anemia do tipo leve $(9 \mathrm{~g} / \mathrm{dL}<$ hemoglobina $<12 \mathrm{~g} / \mathrm{dL}$ ). Escolares do sexo feminino apresentaram médias de concentrações de hemoglobina menores em todas as faixas etárias $(p<0,001)$. Não foi observada associação entre concentrações de hemoglobina, estado nutricional $(p>0,05)$ e características socioeconômicas e demográficas ( $p>0,05)$.

\section{Conclusão}

Embora a prevalência de anemia tenha sido discreta e classificada em grau leve, recomenda-se a adoção de medidas preventivas de educação nutricional, com a difusão da alimentação saudável nas escolas e o incentivo ao consumo de alimentos que sejam fonte de ferro.

Termos de Indexação: Anemia. Adolescente. Estado nutricional. Epidemiologia. Fatores socioeconômicos.

\section{INTRODUCTION}

Anemia results from a variety of causes that can occur separately or in combination. Overall, the most significant contribution to an anemic condition is iron deficiency, called, "iron deficiency anemia" or simply "anemia"1.

Anemia is a global public health problem, occurring in both developing and developed countries $^{2}$. It is a nosological entity that is associated to delayed cognitive and psychomotor development ${ }^{3}$, changes in growth and development, mood swings, lower exercise tolerance ${ }^{4-6}$, fatigue, difficulty in concentration, which can impair the learning capabilities of children and adolescents. In turn, this deficiency condition can cause the impairment of cellular immunity, induce reduced appetite, and lead to perverse eating behavior, headaches, dizziness, pale complexion and mucosa, and gastrointestinal disorders and, even, signs of heart failure ${ }^{5.6}$.

Adolescence is the period of transition between childhood and adulthood, with somatic, psychological and social changes. This stage of life is marked by intense physiological changes (menstrual blood loss in girls and increased muscle mass, arising from the pubertal growth spurt and biological development - bone and sexual), which may influence the level of iron in the body. At this stage of life, iron deficiency is a complex condition, in that several factors may be involved, beyond those of a biological and nutritional nature, notably the psychological changes, as well as social and cultural influences (body image, peer and media influences) ${ }^{7}$.

During this phase of the life cycle dietary iron deficiency is the main source of risk leading to anemia, although there are other causes, such 
as infectious diseases and nutritional deficiencies, such as, in vitamin A, vitamin $B_{12}$ and folic acid-11, in other words, it is a nutritional disorder of multifactorial origin ${ }^{10}$.

Nutritional anemia is a condition in which the Hemoglobin Content $(\mathrm{Hb})$ in the blood is below normal levels, due to the lack of one or more of the essential nutrients that are necessary for the formation of $\mathrm{Hb}^{6}$. Although there are other indicators that are used in the definition of anemia, World Health Organization (WHO) considers the concentration of $\mathrm{Hb}$ as the most appropriate indicator for epidemiological studies and for tracking purposes ${ }^{12,13}$.

A recent publication by $\mathrm{WHO}$ on the estimated global prevalence of anemia, between 1993 and 2005, showed that it occurred in 54.6\% of the children of preschool age in Brazil. This figure was calculated by weighting the prevalence observed in only two geographical areas (Recife $[\mathrm{PE}]$ and São Paulo [SP] ${ }^{14}$. In Brazil, despite the absence of multi-center or national surveys, there is consensus in the scientific community that irondeficiency anemia is highly prevalent throughout Brazil, reaching all social classes and age groups. In regional studies, a rate of $20.0 \%$ for the prevalence of anemia among adolescents was estimated ${ }^{15}$.

The aim of this study was to estimate the prevalence of anemia and to identify the risk factors that are associated to this nutritional deficiency in adolescents from Recife (PE), Brazil.

\section{METHODS}

\section{Design of study and sample}

The study design is of the cross-sectional type, nested within a cohort entitled "Dyslipidemia and its association with an overweight condition in a cohort of schoolchildren from Recife, PE", started in 2007. This cross-sectional study involved a random sample of 256 adolescents, aged between 13-18 years, of both sexes, enrolled in state and municipal schools of the official school network of the city of Recife (PE), in the period from June 2011 to September 2012. Those adolescents who were not found at school were contacted and evaluated in their homes using the school address register.

The sample excluded those adolescents who showed symptoms of having an acute disease on the day of the laboratory test and which entailed changes in $\mathrm{Hb}$ levels, those who had any physical disabilities that compromised anthropometric measurements and those who were taking multivitamins or had received treatment for anemia in the past two months.

The hemoglobin concentrations, nutritional condition and socio-economic and demographic characteristics were evaluated in the study.

To define the sample size the study used an estimated prevalence ( $p$ ) of $9 \%$ of students with unsatisfactory $\mathrm{Hb}$ concentrations, based on the results of a pilot study, with a margin of error of $3 \%(d)$ and a Confidence Interval $(Z=1.96)$ of $95 \%$. The sample size was calculated using the following formula: $N=Z^{2} \times p x(100-p) / d^{2}$. The required minimum sample size was 350 adolescents. Since the sample was selected from a finite population of a cohort of 669 school children, it was adjusted using the formula $N=n /[1+(n / N)]$, where $N$ is the population and $n$ the minimum sample size, resulting in a total of 230 adolescents to be investigated. To correct for possible losses, the sample size was set at $12 \%$ [100/(100-12)], making a total of 263 adolescents.

\section{Evaluation methods and techniques}

Hemoglobin Concentrations: $2 \mathrm{~mL}$ of blood was collected by venipuncture and deposited in Vacuntainer tubes, using Ethylene Diamine Tetraacetic Acid (EDTA) as an anticoagulant. The samples were sent to the Laboratory of Clinical Analysis and were interpreted using a $\mathrm{LH}$ 750 Hematology Analyzer (Beckman Coulter, Brea, CA, USA). 
The hemoglobin content concentration was measured in grams per deciliter $(\mathrm{g} / \mathrm{dL})$ and anemia was considered to be present when the $\mathrm{Hb}$ level was below $12 \mathrm{~g} / \mathrm{dL}$ for non-pregnant female and male adolescents aged between 12-14 years. For adolescents older than 15 years an $\mathrm{Hb}$ level below $13 \mathrm{~g} / \mathrm{dL}^{6}$ was considered to indicate the presence of anemia.

Anthropometric evaluation: Anthropometric measurements were performed by taking two readings of the weight and height of the adolescents. The average values were used for the formal registration of the measurements. To ensure data consistency, measurements that showed differences of more than $100 \mathrm{~g}$ in weight, or $0.5 \mathrm{~cm}$ in height were discarded. Body weight was measured using a digital electronic scale (Omron, Kyoto, Japan), with a maximum capacity of $150 \mathrm{~kg}$ and a precision of $100 \mathrm{~g}$. The adolescents were weighed, barefoot, without objects in their hands and pockets or on their heads. Height was measured using a portable stadiometer (Alturexata, Belo Horizonte, MG, Brazil), with a precision of $1 \mathrm{~mm}$ and accuracy of $0.5 \mathrm{~cm}$. The adolescents were positioned upright, barefoot, with the upper limbs aligned to the body, the heels, the back and head touching the wall, and the eyes looking straight ahead. The measurements of weight and height followed the recommendations of Lohman et al. ${ }^{16}$ and were conducted at schools or in homes.

For the classification of the adolescents nutritional condition, indicators of Height for Age $(\mathrm{H} / \mathrm{A})$ and Body Mass Index for Age (BMI/A), expressed as Z-score values, were used, according to the classification of the World Health Organization ${ }^{17}$.

Socio-economic and demographic characteristics: Personal data and information on the adolescents' social, economic and demographic situations were collected through interviews at the schools or during the home visits.

Gender, age and level of education of the adolescents were analyzed. Age in years was classified in the ranges of 13-15, 15-17 years and
17-18 years, and the level of education was classified in the ranges of Elementary School $\left(6^{\text {th }}\right.$ year to $9^{\text {th }}$ year) and High School ( $1^{\text {st }}$ year to third year). The parents' level of education was classified as either less than or equal to 8 years of schooling and over 8 years of schooling and cases of school year repetition were noted. For the classification of the socio-economic level of the families, the study used the "Economic Classification Criteria of Brazil", established by the Brazilian Association of Research Companies ${ }^{18}$. Families were classified according to their average incomes. Those with income in the range of $\geq R \$ 1,391.00$ and $<R \$ 2,327.00$ were included in classes $B_{2}$ and $C_{1}$, those with income $<R \$ 1,391.00$ and $\geq R \$ 933.00$ in the class $C_{2}$ and those with income $<R \$ 933.00$ and $\geq R \$ 618.00$ in class $D$.

\section{Data analysis}

The data was entered in duplicate and verified using the Validate module of the Epi Info program, version 6.04 (WHO/Centers For Disease Control [CDC], Atlanta, Georgia [GA], USA), to check for any inconsistencies in typing. The statistical analysis was performed using Statistical Package for the Social Sciences (SPSS) for Windows version 13.0.

The continuous variables were tested for normal distribution using the KolmogorovSmirnov test. The $\mathrm{Hb}$ values were expressed as an average and a standard deviation. The $\mathrm{Hb}$ concentrations were evaluated for the adjustment variables, using Levene's variance homogeneity test, followed by the Student $t$ test to identify associations with the variables: gender, level of education, school year repetition and level of parental education. A Variance Analysis (Anova) was performed for the variables of age and nutritional condition. The socio-economic level and $\mathrm{Hb}$ concentrations were evaluated using the Kruskal Wallis test. For the description of the proportions, the binomial distribution was approximated to the normal distribution, with a 
$95 \% \mathrm{Cl}$. A significance level of $5 \%$ to reject the null hypothesis was adopted.

\section{Ethical aspects}

The research Protocol was approved by the Committee for Research Ethics of the Pernambuco Cancer Hospital (02/2010). All the adolescents who participated in the study were informed of the research objectives and the methods and techniques to be adopted; with the teenager's permission, a parent or guardian signed a Free Consent Form and received a copy of the the results of the examination.

\section{RE S U L T S}

Of the sample of 263 students, there were seven losses due to the inadequacy of the biological material collected, inconsistency in the control variable data and/or refusal of the student to participate in the study Protocol.

The socio-economic and demographic characteristics and nutritional condition are described in Table 1.

The prevalence of anemia was $10.2 \%$ [95\% $\mathrm{Cl}=6.74-14.52]$ and the unsatisfactory $\mathrm{Hb}$ concentrations were in a range classified as mild anemia $(9<\mathrm{Hb}<12 \mathrm{~g} / \mathrm{dL})$.

The hemoglobin contend concentrations showed an association with gender, with female students showing a higher occurrence of unsatisfactory $\mathrm{Hb}$ concentrations (Table 2). This pattern of association occurred in all of the age groups in our sample (Table 3). On the other hand, the $\mathrm{Hb}$ concentrations were not shown to be associated with any other socio-economic or demographic variable, nor with nutritional condition ( $p>0.05$ ) (Table 2).

\section{DISCUSSION}

The prevalence of anemia in adolescents in Recife (PE) represents a public health problem at a mild level, since the percentage falls within the range $5 \%-19 \%$, which is the level of the problem used by WHO for such classification ${ }^{6}$. The level of anemia found in the adolescents was

Table 1. Characteristics of the sample of adolescents aged between 13-18 years from Recife, broken down by socio-economic and demographic factors and nutritional condition, 2011-2012.

\begin{tabular}{|c|c|c|c|}
\hline Variables & $n$ & $\%$ & $95 \% \mathrm{Cl}$ \\
\hline \multicolumn{4}{|l|}{ Gender } \\
\hline Male & 107 & 41,8 & $35.60-48.1$ \\
\hline Female & 149 & 58,2 & $51.96-64.3$ \\
\hline \multicolumn{4}{|l|}{ Age (years) } \\
\hline $13-15$ & 105 & 41,0 & $34.90-47.3$ \\
\hline $15-17$ & 106 & 41,4 & $35.30-47.7$ \\
\hline $17-18$ & 45 & 17,6 & $13.10-22.8$ \\
\hline \multicolumn{4}{|l|}{ School series } \\
\hline Elementary school & 150 & 60,2 & $53.80-66.3$ \\
\hline Secondary school & 99 & 39,8 & $33.60-46.1$ \\
\hline \multicolumn{4}{|l|}{ School year repetition } \\
\hline Yes & 103 & 40,4 & $34.30-46.7$ \\
\hline No & 152 & 59,6 & $53.30-65.7$ \\
\hline \multicolumn{4}{|l|}{ Education level } \\
\hline \multicolumn{4}{|l|}{ Father } \\
\hline$\leq 8$ years & 114 & 64,0 & $56.50-71.1$ \\
\hline$>8$ years & 64 & 36,0 & $28.90-43.5$ \\
\hline \multicolumn{4}{|l|}{ Mother } \\
\hline$\leq 8$ years & 155 & 70,4 & $63.90-76.4$ \\
\hline$>8$ years & 65 & 29,5 & $23.60-36.0$ \\
\hline \multicolumn{4}{|l|}{ Socio-economic leve/1 } \\
\hline $\mathrm{B}_{2}$ and $\mathrm{C}_{1}$ & 108 & 46,9 & $40.40-53.6$ \\
\hline $\mathrm{C}_{2}$ & 92 & 40,0 & $33.60-46.6$ \\
\hline$D$ & 30 & 13,1 & $8.90-18.1$ \\
\hline \multicolumn{4}{|l|}{ Nutritional condition } \\
\hline \multicolumn{4}{|l|}{ Height/age $^{2}$} \\
\hline Low & 7 & 3,1 & $0.8-5.4$ \\
\hline Satisfactory & 212 & 94,6 & $91.7-97.5$ \\
\hline High & 5 & 2,3 & $0.40-4.2$ \\
\hline \multicolumn{4}{|l|}{ BMIlage $^{3}$} \\
\hline Underweight & 13 & 5,8 & $2.80-8.8$ \\
\hline Eutrophic & 158 & 70,5 & $64.60-76.4$ \\
\hline Overweight & 53 & 23,7 & $18.10-29.3$ \\
\hline
\end{tabular}

Note: ${ }^{1}$ Associação Brasileira de Empresas de Pesquisa ${ }^{18}$ : Class $\mathrm{B}_{2}$ and $C_{1}(\geq R \$ 1,391.00$ and $<R \$ 2,327.00)$, Class $C_{2}(<R \$ 1,391$ and $\geq R \$ 933.00)$, Class $D(<R \$ 933.00$ and $\geq R \$ 618.00) ;{ }^{2}$ Low: $<$ Score-2; Satisfactory: $\geq$ Score $-2 \leq$ Score +2 , High: $<$ Score +2 ; ${ }^{3}$ Underweight: $<$ Score -2.0, Eutrophic: $\geq$ Score-Z $-2 \leq 1$; Overweight: $>$ Score-Z +1 . 95\% Cl: $95 \%$ Confidence interval; BMI: Body Mass Index. 
Table 2. Hemoglobin concentrations in adolescents aged 13-18 years from Recife (PE), broken down by socio-economic and demographic factors and nutritional condition, 2011-2012.

\begin{tabular}{|c|c|c|c|c|}
\hline \multirow{2}{*}{ Variables } & \multicolumn{4}{|c|}{ Hemoglobin concentrations $(\mathrm{g} / \mathrm{dL})^{*}$} \\
\hline & $n$ & $\bar{x}$ & SD & $p^{* *}$ \\
\hline \multicolumn{5}{|l|}{ Gender } \\
\hline Male & 107 & 14.2 & 1.0 & \multirow[t]{2}{*}{0.00} \\
\hline Female & 149 & 12.9 & 0.7 & \\
\hline \multicolumn{5}{|l|}{ Age (years) } \\
\hline $13-15$ & 105 & 13.3 & 1.0 & \multirow{3}{*}{0.27} \\
\hline $15-17$ & 106 & 13.6 & 1.2 & \\
\hline $17-18$ & 45 & 13.4 & 1.2 & \\
\hline \multicolumn{5}{|l|}{ School series } \\
\hline Elementary school & 150 & 13.4 & 1.1 & \multirow{2}{*}{0.98} \\
\hline Secondary school & 99 & 13.4 & 1.1 & \\
\hline \multicolumn{5}{|l|}{ School year repetition } \\
\hline Yes & 103 & 13.5 & 1.2 & \multirow{2}{*}{0.53} \\
\hline No & 152 & 13.4 & 1.0 & \\
\hline \multicolumn{5}{|l|}{ Education level } \\
\hline \multicolumn{5}{|l|}{ Father } \\
\hline$\leq 8$ years & 114 & 13.5 & 1.1 & \multirow{2}{*}{0.18} \\
\hline$>8$ years & 64 & 13.2 & 1.0 & \\
\hline \multicolumn{5}{|l|}{ Mother } \\
\hline$\leq 8$ years & 155 & 13.4 & 1.2 & \multirow{2}{*}{0.76} \\
\hline$>8$ years & 65 & 13.4 & 1.0 & \\
\hline \multicolumn{5}{|l|}{ Socioeconomic lever ${ }^{2}$} \\
\hline $\mathrm{B}_{2}$ and $\mathrm{C}_{1}$ & 108 & $13.3^{3}$ & {$[12.7 \text { to } 14.1]^{4}$} & \multirow{3}{*}{$0.97^{5}$} \\
\hline$C_{2}$ & 92 & $13.4^{3}$ & [12.6 to 14.3$]^{4}$ & \\
\hline D & 30 & $13.2^{3}$ & {$[12.3 \text { to } 14.7]^{4}$} & \\
\hline \multicolumn{5}{|l|}{ Nutritional condition } \\
\hline \multicolumn{5}{|l|}{ Height/age $^{2}$} \\
\hline Low $^{6}$ & 7 & 13.7 & 1.2 & \multirow{3}{*}{0.87} \\
\hline Satisfactory & 212 & 13.5 & 1.1 & \\
\hline High & 5 & 13.4 & 0.6 & \\
\hline \multicolumn{5}{|l|}{ BMI/age ${ }^{3}$} \\
\hline Underweight & 13 & 13.6 & 1.1 & \multirow{3}{*}{0.82} \\
\hline Eutrophic & 158 & 13.4 & 1.1 & \\
\hline Overweight ${ }^{7}$ & 53 & 13.5 & 1.2 & \\
\hline
\end{tabular}

Note: ${ }^{*} \mathrm{Hb}<12 \mathrm{~g} / \mathrm{dL} 12-14$ years and in females. From 15 years, $\mathrm{Hb}<13 \mathrm{~g} / \mathrm{dL}$ in males ${ }^{6}$, student $t$ test; ${ }^{* *}$ for unpaired data; ${ }^{1}$ Anova; ${ }^{2}$ Associação Brasileira de Empresas de Pesquisa18: Class $B_{2}$ and $C_{1}(\geq R \$ 1,391.00$ and $<R \$ 2,327.00)$, Class $C_{2}(<R \$ 1,391$ and $\geq R \$ 933.00)$, Class $D(<R \$ 933.00$ and $\geq R \$ 618.00) ;{ }^{3}$ Median; ${ }^{4}$ Inter-quartile range; ${ }^{5}$ Kruskal Wallis; ${ }^{6}$ Low: $<$ Score -2 ; Satisfactory: $\geq S c o r e-2$ and $\leq$ Score +2 , High: $<$ Score $+2 ;{ }^{7}$ Underweight: <Score -2.0, Eutrophic: $\geq Z-2$ and $\leq 1$; Overweight: $>$ Score-Z +1 .

SD: Standard Deviation; BMI: Body Mass Index.

of the mild type $(9<\mathrm{Hb}<12 \mathrm{~g} / \mathrm{dL})$. These findings could be attributed to the National Iron Supplement Program which was implemented by the Ministry of Health in 1999, in compliance with the Politica Nacional de Alimentação e Nutrição
(PNAN, National Food and Nutrition Policy). This led to the fortification of wheat and corn flour with iron and folic acid, a low cost supplement used to prevent nutritional deficiencies of this nature. In 2001, flour fortification became 
Table 3. Concentrations of hemoglobin in anemic teenagers aged 13-18 years, of both sexes enrolled in the public schools of Recife (PE). 2011-2012.

\begin{tabular}{|c|c|c|c|c|c|}
\hline \multirow{3}{*}{ Age (years) } & \multicolumn{4}{|c|}{ Hemoglobin $(\mathrm{g} / \mathrm{dL})$} & \multirow{3}{*}{$p^{* *}$} \\
\hline & \multicolumn{2}{|c|}{ Male } & \multicolumn{2}{|c|}{ Female } & \\
\hline & $n$ & $X \pm S D^{*}$ & $\mathrm{n}$ & $X \pm S D^{*}$ & \\
\hline $13-15$ & 2 & $14.0 \pm 1.0$ & 6 & $12.9 \pm 0.7$ & $<0.01$ \\
\hline $15-17$ & 3 & $14.4 \pm 1.0$ & 9 & $12.9 \pm 0.8$ & $<0.001$ \\
\hline $17-18$ & 1 & $14.6 \pm 0.8$ & 5 & $12.8 \pm 0.8$ & $<0.001$ \\
\hline Total & 6 & $14.3 \pm 1.0$ & 20 & $12.9 \pm 0.8$ & $<0.001$ \\
\hline
\end{tabular}

Note: *Average \pm Standard Deviation (SD), student $t$ test; ${ }^{* *}$ Non-paired data.

mandatory. In turn, school lunches have contributed to better student nutrition ${ }^{19}$, since the National School Food Program allows and focuses on the contribution of this micro-nutrient which is added to the regional meals offered to students. Thus, the addition and control of iron content in food have been ensured, which may have contributed to the predominance of the occurrence of mild anemia in this age group.

This level of prevalence was similar to that found in other studies in Brazil, such as Rezende et al. ${ }^{20}$, who conducted a study in Novo Cruzeiro (MG) in 2000 and found that $12.1 \%$ of students had unsatisfactory $\mathrm{Hb}$ concentrations. Similar results in the category of prevalence of mild anemia were also observed by Rosa \& Baldacci4, in 2008/2009, at the Health Unit of Rio Branco (AC) with $6.8 \%$, and Mariath et al. ${ }^{21}$ in 2007 in Itajaí (SC) with $9.7 \%$. This data contrasts with the much higher prevalence observed in population surveys carried out in Latin America, such as the study by Leal et al. ${ }^{22}$, which reported a prevalence of anemia of 39.35 and Ortega et al. ${ }^{10}$, with a prevalence of $48.6 \%$, in $2003 / 2004$, in Venezuela, as well as a prevalence of $28.5 \%$ reported by Manjarrés et al. ${ }^{9}$, in 2005 in Colombia. Similar results were reported in a study conducted in 2007 by Ferrari et al. ${ }^{23}$, in 2007, with a prevalence of $17.6 \%$ in ten European cities.

The percentage of school year repetition observed in our sample is of concern, which would explain the fact that most of the adolescents were still at elementary school. However, one should take into account that $\mathrm{Hb}$ concentrations were shown to be equivalent among students with elementary education and high school education, as well as between those that had repeated school years versus those who had not. It would be plausible to assume that adolescents with anemia would have a higher propensity for school year repetition, since this nutritional disorder can cause decreased attention, fatigue and learning difficulties, thus adversely affecting school performance. It should also be noted that for the period of education of the adolescents under study, the system of partial school year progression permitted by the Law of Guidelines and Bases for Education, passed in 1996, was legally being applied by certain Brazilian states in that year and was adopted by the Pernambuco State Education System in 1997. However, those students that failed in more than three subjects in their basic education were obliged to repeat years of schooling.

The low level of education of the parents, where a significant percentage had less than eight years of study, has also been observed in other studies, such as the research developed by Nishida et al. ${ }^{24}$ in Maringá (PR). The low level of parental education appears to be a factor that can contribute, significantly, to a situation where the education level of adolescents does not corresponding to their chronological age, since parents with a higher education level tend to encourage their children to learn ${ }^{25}$. The low education level of parents could, in principle, interfere with the adolescent's chances of having 
anemia, since it is expected that the children of mothers with higher levels of education are less likely to have unhealthy eating patterns, compared to those born to mothers with a lower level of education ${ }^{11}$.

The lack of association between $\mathrm{Hb}$ concentrations and socio-economic level is in line with the study of Farias et al. ${ }^{26}$, that demonstrated the relationship between family per capita income and the prevalence of anemia, since it is expected that the level of income may influence the quantity and quality of the consumption of ironrich foods ${ }^{27}$.

The greater probability of female adolescents having unsatisfactory $\mathrm{Hb}$ concentrations confirms that females are a higher risk group for iron deficiency ${ }^{2,10}$. This greater vulnerability could be due to menstrual loss ${ }^{22,23}$. These findings have been corroborated by other studies ${ }^{21,28}$ that evaluated the distribution of anemia in relation to girls in groups of adolescents.

Unlike the studies with preschool children who have a higher prevalence of anemia among children under 2 years of age ${ }^{5}$, it can be seen that during adolescence, age is not a modifying factor in $\mathrm{Hb}$ concentrations.

An association between low weight and unsatisfactory $\mathrm{Hb}$ concentrations would be expected. In our sample, where the majority of adolescents was classified as eutrophic, it would indicate that anemia could occur as a specific nutritional deficiency in individuals, independently of their protein-energy nutritional condition. This lack of association corroborates with the data collected by Ortega et al. ${ }^{10}$, which sought to relate the BMI in adolescent girls with anemia and/or risk of depletion of body iron stores and found no association between these variables.

The authors have assumed that iron depletion would be greater among adolescents with a higher BMI (overweight), due to sedentary habits and a poor quality diet with a low iron intake. Other studies ${ }^{11.29}$ also found no direct relationship between anemia/iron deficiency and an overweight condition. However, Tussing-
Humphreys et al. ${ }^{30}$ studying obese children and adolescents found an inverse association between adiposity and the iron level, explained by the fact that the increase in food consumption would not encompass foodstuffs that were sources of iron.

It is important to stress that the main limitation of this investigation results from the fact that the use of $\mathrm{Hb}$ concentrations as the sole proxy for the definition of iron-deficiency anemia, without additional data on other parameters of the iron nutritional condition, such as ferritin and serum iron, total iron binding capacity, percentage transferrin saturation, free enythrocyte protoporphyrin and, especially, the transferrin receptors. Other limiting factors were, on the one hand, the lack of data on the dietary iron intake of students and, on the other, the adoption of a cross-sectional methodological design that allowed only the observation of associations between the events studied, without being possible to demonstrate a cause and effect relationship between these events ${ }^{27}$.

\section{CONCLUSION}

The prevalence of anemia observed in adolescents in Recife (PE) reached a level that constituted a public health problem of the mild type. The unsatisfactory $\mathrm{Hb}$ concentrations were close to the levels for the diagnostic discrimination point for deficiency, configuring, consequently, mild anemia $(9<\mathrm{Hb}<12 \mathrm{~g} / \mathrm{dL}$ ). Female adolescents showed a greater susceptibility to having anemia, although no other associations between $\mathrm{Hb}$ concentrations and nutritional condition, and the other socio-economic and demographic variables, were observed.

Considering the wide range of specific nutritional deficiencies, which can result in significant adverse effects on health, we see the need to implement preventive and control measures, as well as the dissemination of concepts about healthy eating, with the inclusion of high bioavailability iron-rich foods in school meals. 


\section{ACKNOWLEDGMENTS}

We thank the National Research Council for its financial support. We would also like to thank nutritionists Patricia Brazil and Mellina Albuquerque for helping in the statistical analysis.

\section{CONTRIBUTORS}

EBS MENDONÇA Author of the thesis, responsible for the conception, design, data collection, tabulation and analysis and article write-up. LF MUNIZ Co-supervisor who contributed with data collection and article write-up. IKG ARRUDA Fieldwork coordinator, who contributed towards the data collection, study design and article write-up. AS DINIZ Main supervisor of the research who provided orientation on the tabulation, statistical analysis and write-up of the manuscript and contributed towards data analysis.

\section{REFERENCES}

1. World Health Organization. Worldwide prevalence of anaemia 1993 -2005: WHO global database on anaemia. Geneva: WHO; 2008 [cited 2012 Jan 17]. Available from: <http://whqlibdoc.who.int/ publications/2008/9789241596657_eng.pdf>.

2. Azeredo CM, Cotta RMM, Silva LS, Franceschini SCC, Sant'Ana LRF, Lamounier JA. A problemática da adesão na prevenção da anemia ferropriva e suplementação com sais de ferro no município de Viçosa (MG). Cienc Saúde Colet. 2013; 18(3):827-36. doi: 10.1590/S1413-81232013000300028

3. Serrano $\mathrm{CH}$, Villagrán A, Harris P. Helicobacter pylori: una causa no tradicional de deficiencia de hierro y anemia. Rev Chil Pediatr. 2012; 83(1):13-23. doi: 10.4067/S0370-41062012000100002

4. Rosa MFL, Baldacci ER. Prevalência de anemia em crianças atendidas em Unidade de Saúde de Rio Branco-AC nos meses de março a junho de 2009. Pediatria. 2010; 32(3):157-62.

5. Braga JAP, Vitalle MSS. Deficiência de ferro na criança. Rev Bras Hematol Hemoter. 2010; 32(Supl. 2):38-44. doi: 10.1590/S1516-8484201000500 0054

6. World Health Organization. Iron deficiency anaemia: Assessment, prevention and control. Geneva: WHO; 2001.

7. Garanito MP, Pitta TS, Carneiro JDA. Deficiência de ferro na adolescência. Rev Bras Hematol Hemoter.
2010; 32(2):45-8. doi: 10.1590/\$1516-84842010 005000056

8. Pizarro F, Calvo E. El significado, a mediano y largo plazo, de la deficiencia de hierro y zinc durante los primeros dos años de vida, para asegurar un buen crecimiento temprano. In: Uauy R, Carmuega E, Editor. Impacto del crecimiento y desarrollo sobre la salud y bienestar de la población. Perspectivas y reflexiones del cono sur. Buenos Aires: Instituto Danone Cono Sur; 2009. p.49-64.

9. Manjarrés LM, Díaz A, Carriquiry A. Asociación entre la ingesta de nutrientes hematopoyéticos y el origen nutricional de la anemia en mujeres en edad fértil en Colombia. Rev Panam Salud Publica. 2012; 31(1):68-73.

10. Ortega P, Jorymar Y, Leal M, Amaya D, Chávez CJ. Anemia y depleción de lás reservas de hierro en adolescentes de sexo femenino no embarazadas. Rev Chil Nutr. 2009; 36(2):111-9.

11. Choi $H$, Lee $H$, Jang Han $B$, Park JY, Kang JH, Park $\mathrm{KH}$, et al. Effects of maternal education on diet, anemia, and iron deficiency in Korean school-aged children. BMC Public Health. 2011; 11(1):870.

12. Carvalho AGC, Lira PIC, Barros MFA, Aléssio MLM, Lima MC, Carbonneau MA, et al. Diagnóstico de anemia por deficiência de ferro em crianças do Nordeste do Brasil. Rev Saúde Pública. 2010; 44(3):513-9.

13. Castro TG, Silva-Nunes M, Conde WL, Muniz PT, Cardoso MA. Anemia e deficiência de ferro em préescolares da Amazônia Ocidental brasileira: prevalência e fatores associados. Cad Saúde Pública. 2011, 27(1):131-42.

14. McLean E, Egli I, Cogswell M, Wojdyla D, Benoist B, Worldwide prevalence of anaemia, WHO Vitamin and Minerl Nutrition Information System, 1993-2005. Public Health Nutr. 2009; 12(4):444-54. doi: 10. 1017/S1368980008002401

15. Nunes SMT, Yuyama LKO, Guedes DP, Oliveira MC. Anemia ferropriva em atletas adolescentes da Fundação Vila Olímpica de Manaus-AM. Acta Amaz. 2008; 38(2):263-6.

16. Lohman TG, Roche AF, Martorell R. Anthrometric standardization reference manual. Champaign: Human kinetics; 1988.

17. World Health Organization. Anthro for personal computers. Software for assessing growth and development of the world's children. Version 2. Geneva: WHO; 2007.

18. Associação Brasileira de Empresas de Pesquisa. Critério padrão de Classificação Econômica do Brasil. São Paulo: Abep; 2010 [acesso 2010 jul 1]. Disponível em: <www.abep.org/codigosguias/ Criterio_Brasil_2010.pdf>. 
19. Vellozo EP, Fisberg M. A contribuição dos alimentos fortificados na prevenção da anemia ferropriva. Rev Bras Hematol Hemoter. 2010; 32(2):140-7.

20. Rezende EG, Santos MA, Lamounier JA, Galvão MAM, Leite RC. Deficiência de ferro e anemia em escolares da área rural de Novo Cruzeiro (Minas Gerais) Brasil. Rev Med Minas Gerais. 2009; 19(2):103-8.

21. Mariath AB, Giachini RM, Lauda LG, Grillo LP. Estado de ferro e retinol sérico entre crianças e adolescentes atendidos por equipe da Estratégia de Saúde da Família de Itajaí, Santa Catarina. Ciênc Saúde Colet. 2010; 15(2):509-16.

22. Leal JY, Romero TB, Ortega P, Chávez CJ. Interleucina-10 e interféron gamma en adolescentes de sexo femenino anêmicas con depósitos de hierro depletados. Rev Chil Nutr. 2008; 35(2):101-8.

23. Ferrari M, Mistura L, Patterson E, Sjostro M, Dýaz $L E$, Stehle $P$, et al. Evaluation of iron status in European adolescents through biochemical iron indicators: The HELENA Study. Eur J Clin Nutr. 2011; 65(3):340-9.

24. Nishida FSI, Uchimura TTI, Szarfarc SC, Bossato TF, Nahida Ajala CV, Uchimura NS. Prevalência de anemia em escolares de escolas públicas de MaringáPR, 2008. Rev Eletrônica Enfem. 2010; 12(2):237-44. doi: 10.5216/ree.v12i2.6430
25. Reis MC, Ramos L. Escolaridade dos pais, desempenho no mercado de trabalho e desigualdade de rendimentos. Rev Bras Econ. 2011; 65(2):177-205.

26. Farias ILG, Colpo E, Pereira WV, Luchesi M, Ambros G, Silva JEP. Tempo de tratamento para atingir níveis de normalidade na anemia ferropriva. Rev Bras Anal Clin. 2009; 41(1):9-13.

27. Borges CQ, Silva RCR, Assis AMO, Pinto EJ, Fiaccone $\mathrm{RL}$, Pinheiro SMC. Fatores associados à anemia em crianças e adolescentes de escolas públicas de Salvador, Bahia, Brasil. Cad Saúde Pública. 2009; 25(4):877-88.

28. Cócaro ES, Fisberg M. Anemia Ferropriva em adolescentes praticantes de tênis de campo. Nutrire. 2009; 34(Supl.):328-8.

29. Mochonis G, Chrousos GP, Lionis C, Mougios V, Manios $Y$. Association of total body and visceral fat mass with iron deficiency in preadolescents: The Healthy Growth Study. Br J Nutr. 2012; 108(4):710-9. doi: $10.1017 /$ S0007114511005952

30. Tussing-Humphreys LM, Nemeth E, Fantuzzi G, Freels S, Holterman AL, Galvani C, et al. Decreased serum hepcidin and improved functional iron status 6 months after restrictive bariatric surgery. Obesity. 2010; 18(10):2010-6. doi: 10.1038/oby.2009.490

Received on: 12/12/2013

Final version on: 7/16/2014

Approved on: 8/5/2014 